\title{
Screening for six genetically modified soybean lines by an event-specific multiplex PCR method: Collaborative trial validation of a novel approach for GMO detection
}

\author{
Lutz Grohmann ${ }^{1}\left[\right.$ Anke Belter $^{2} \cdot$ Brigitte Speck $^{3} \cdot$ Ottmar Goerlich $^{4}$ • \\ Patrick Guertler $^{4} \cdot$ Alexandre Angers-Loustau $^{5} \cdot$ Alex Patak $^{5}$
}

Received: 23 August 2016/Accepted: 6 October 2016/Published online: 5 November 2016

(c) The Author(s) 2016. This article is published with open access at Springerlink.com

\begin{abstract}
This study presents a novel approach to detect genetically modified (GM) plant events that are not covered by common GMO screening methods. It is based on a simplified multiplex assay which merges the event-specific real-time PCR methods for the detection of six GM soybean lines (MON 87701, MON 87708, MON 87769, DP-305423, CV-127 and DAS-68416). The use of two different fluorescent dyes facilitates the subsequent analysis for identification of the GM event. The multiplex PCR method was validated in a collaborative study trial with 16 participating laboratories. Each laboratory received eight samples containing low levels $(0.1 \%$ or $0.03 \%$ $\mathrm{m} / \mathrm{m}$ ) of one or two GM soybean lines and four GMnegative samples. Data of 720 PCR analyses were evaluated and a false-positive rate of $0.3 \%$ and a falsenegative rate of $3.9 \%$ was observed, respectively. The limits of detection (LOD 95\%) were calculated based on modelling the probability of detection (POD) and show satisfactory sensitivity and reproducibility for the assay. Furthermore, we discuss the modularity
\end{abstract}

Lutz Grohmann

lutz.grohmann@bvl.bund.de

1 Federal Office of Consumer Protection and Food Safety, Mauerstr. 39-42, 10117 Berlin, Germany

2 Environmental Protection Agency of Saxony-Anhalt, Reideburgerstr. 47, 06114 Halle, Germany

3 Center for Agricultural Technology Augustenberg, Neßlerstr. 25, 76227 Karlsruhe, Germany

4 Bavarian Health and Food Safety Authority, Veterinärstr. 2, 85764 Oberschleißheim, Germany

5 Joint Research Centre, European Commission, Via Enrico Fermi 2749, 21027 Ispra, Italy and applicability of event-specific multiplex PCR systems for the detection of GM events that are not covered by screenings.

Keywords Genetically modified soybean .

Screening · Multiplex real-time PCR .

Collaborative trial · Probability of detection (POD)

\section{Introduction}

According to the European legislation, the detection of genetically modified (GM) plants and monitoring of food, feed and seeds is commonly achieved by using PCR-based screening methods targeting genetic elements or constructs that are frequently present in GM plants. With the constant growth rate of commercialised and cultivated GM plants, the diversity of functional traits and the heterogeneity of expressed genes have further increased. Current GMO screening strategies are based on a so-called "matrix approach" using defined sets of real-time PCR screening methods (CEN 2014; ENGL 2015). These sets target the genetic elements and constructs that are frequently inserted into GM plant genomes, e.g. CaMV P-35S, P-FMV, T-nos, bar, epsps, pat, cry1Ab/Ac, cpt2-cp4 epsps and P35S - pat (Waiblinger et al. 2010; Gerdes et al. 2012; Scholtens et al. 2013).

If the GMO coverage of these screening assays is checked, it becomes apparent, that particularly soybean events, which are in the pipeline of EU authorisation or already authorised for commercial use, are not detected by limited screening sets (EUginius 2016; Angers-Loustau et al. 2014). Currently, 25 single and 11 stacked soybean events are approved 
and commercialised at least in one country $(\mathrm{BCH}$ 2016; EU 2016; EUginius 2016). A direct and practicable way to detect GM events is to apply the single event-specific methods provided by the European Union Reference Laboratory for GM Food and Feed (EURL-GMFF) according to Regulation (EC) No. 1829/2003, if available (EU 2003; Bonfini et al 2012). Detection of any GM soybean event in seed lots becomes particularly more important since European initiatives have launched programmes to increase non-GM soybean protein production, based on largescale soybean cultivation in the EU (De Visser et al. 2014; Anonymous 2016).

Multiplex PCR for simultaneous detection of more than one target is an efficient approach for enhanced screening capability. Validated duplex, triplex and pentaplex assays combining element- and constructspecific real-time PCR methods are available and allow time- and cost-reduced GMO screening (Waiblinger et al. 2008; Bahrdt et al. 2010; Dorries et al. 2010; Huber et al. 2013). These multiplex TaqMan PCR assays are based on probes labelled by up to five different fluorescent dyes for simultaneous detection of the different target sequences. Another type of multiplex assay is the combination of event-specific real-time PCR methods that allows the detection and relative quantification of several GM soybean lines (Köppel et al. 2012, 2014). As a prerequisite for application, these assays require a real-time PCR instrument that can efficiently discriminate between the different fluorescent dyes without spectral overlap and crosstalk. In addition, the laboratory staff must be trained well for such a sophisticated application and for reliable sample analysis. Duplex PCR is less complex and has several advantages over singleplex PCR. Therefore, a duplex method for detection of P-35S and T-nos (Waiblinger et al. 2008) is routinely applied by many GMO testing laboratories because of its easy handling.

The aim of our study was to develop a multiplex real-time PCR assay that applies not more than two dyes and thereby can easily be implemented in routine GMO testing laboratories for screening soy GM events that are not covered according to the wellknown Waiblinger screening table (Waiblinger et al. 2010). As a starting point, we considered that corresponding EURL-GMFF reference methods for eventspecific qPCR based detection are available. Secondly, we assumed that these singleplex real-time PCR methods could be combined in a multiplex PCR assay. We aimed to keep the assay simple and modular, without using different fluorescent dyes for detection of the individual GM plant events. At the time we began the study, six GMO soybean events (MON 87701, MON 87708, MON 87769, DP-305423, CV-127 and DAS68416) were identified as not being covered by the Waiblinger screening table. Protocols for six single event-specific real-time PCR methods using fluorescein amidite (FAM) labeled TaqMan probes and certified reference materials are publicly available (Bonfini et al. 2012). If the six methods combine in one PCR reaction, a positive FAM fluorescence signal would indicate a positive screening result for at least one of the GM soybean events, without knowing specifically which of the GM event(s) actually is present in the sample. In the second step of the analysis, the positive screening result is verified by using the event-specific PCR tests in singleplex.

In the present study, we describe the design and adaption of six singleplex event-specific qPCR reference methods to a simplified multiplex PCR screening assay. As a first step, the assay was tested by two laboratories in order to evaluate its inter-laboratory transferability and practicability if used with different equipment and by different operators. Via a collaborative trial with 16 participating laboratories, a further methods performance evaluation of the false positive/negative rate and the inter-laboratory reproducibility of the probability of detection (POD) was conducted (Uhlig et al. 2015). We present the results of the validation studies and discuss the potential modularity and applicability of these multiplex assays in other GM crop plants, screening platforms, and applications.

\section{Materials and methods}

\subsection{Sample materials}

For the preparation of samples for the collaborative trial, certified reference materials (soybean powders) for MON 87701 (AOCS 0809-A), MON 87708 (AOCS 0311-A), MON 87769 (AOCS 0809-B), CV-127 (AOCS 0911-C) and non-GM material (AOCS 0906-A) were purchased from AOCS (Boulder, USA). Materials for DP-305423 (ERM-BF426b; 0.5\% m/m) and DAS-68416 (ERM-BF432b; $0.5 \% \mathrm{~m} / \mathrm{m}$ ) were purchased from the IRMM (Geel, Belgium). Other reference materials for the specificity tests were purchased from AOCS or IRMM.

\subsection{Plasmid DNAs}

Control plasmid samples were kindly provided by the EURL GMFF (Ispra, Italy). These plasmids were 
constructed by cloning of the fragments that span the junction region of the GM insertion to the genomic DNA in the respective GM event according to the target sequence of the published reference methods. According to provider information, the concentrations were adjusted to approximately 2000 copies/ $\mu \mathrm{l}$ on basis of the spectrophotometrically measured concentration and the molecular mass of the plasmid.

Verification of plasmid DNA concentrations was done by singleplex digital droplet PCR (ddPCR) after the collaborative trial. A total of $2 \mu \mathrm{l}$ of plasmid DNA (undiluted, 1:2 and 1:4 diluted) were added to $18 \mu \mathrm{l}$ of ddPCR reaction mix containing $10 \mu \mathrm{l} 2 \times$ ddPCR supermix (Bio-Rad, Hercules, USA) and primers and probe dissolved in PCR grade water (Table 1). Water also served for the negative PCR control. Droplets were generated using 8-well cartridges in a droplet generator, which is part of the QX100 Droplet Digital PCR System (Bio-Rad, Hercules, USA). Droplets were transferred to a 96-well plate and underwent conventional PCR using a T100 thermal cycler (Bio-Rad, Hercules, USA). Cycling conditions were 10 minutes initial denaturation at $95{ }^{\circ} \mathrm{C}, 45$ cycles of $94{ }^{\circ} \mathrm{C}$ for 30 seconds and $60{ }^{\circ} \mathrm{C}$ for 1 minute, and finally $10 \mathrm{~min}$ utes at $98{ }^{\circ} \mathrm{C}$. A heating ramp rate of $2{ }^{\circ} \mathrm{C}$ per second was applied. After amplification, droplet counting and fluorescence measurement were performed in the QX100 Droplet Reader (Bio-Rad, Hercules, USA). The QuantaSoft software (Bio-Rad, Hercules, USA) was used for data acquisition and analysis. Initial concentrations of the plasmid DNAs were calculated in an Excel spreadsheet using a droplet volume of $0.85 \mathrm{nl}$.

Table 1 Primers and probes used in the study

\begin{tabular}{|c|c|c|c|c|c|}
\hline \multirow[t]{2}{*}{$\begin{array}{l}\text { Method (amplicon } \\
\text { length) }\end{array}$} & \multirow[t]{2}{*}{ Name } & \multirow[t]{2}{*}{ Oligonucleotide Sequence $\left(5^{\prime}-3^{\prime}\right)$} & \multicolumn{2}{|c|}{$\begin{array}{l}\text { Final concentration } \\
{[\mathrm{nmol} / \mathrm{l}]}\end{array}$} & \multirow[t]{2}{*}{ References } \\
\hline & & & $\begin{array}{l}\text { Singleplex } \\
\text { PCR }\end{array}$ & $\begin{array}{l}\text { Multiplex } \\
\text { PCR }\end{array}$ & \\
\hline \multirow[t]{3}{*}{ MON87701 (89 bp) } & MON87701 primer 1 & CgT TTC CCg CCT TCA gTT TAA A & 600 & 300 & \multirow[t]{3}{*}{ Charels et al. (2011) } \\
\hline & MON87701 primer 2 & $\begin{array}{l}\text { Tgg TgA TAT gAA gAT ACA TgC TTA } \\
\text { gCA T }\end{array}$ & 600 & 300 & \\
\hline & MON87701 probe & $\begin{array}{l}\text { HEX-TCA gTg TTT gAC ACA CAC ACT } \\
\text { AAg CgT gCC- BHQ1 }\end{array}$ & 250 & 200 & \\
\hline \multirow[t]{3}{*}{ MON87708 (91 bp) } & MON87708 primer 1 & TCA TAC TCA TTg CTg ATC CAT GTA g & 300 & 300 & \multirow[t]{3}{*}{ Savini et al. (2013) } \\
\hline & MON87708 primer 2 & $\begin{array}{l}\text { AgA ACA AAT TAA CgA AAA gAC AgA } \\
\text { ACg }\end{array}$ & 300 & 300 & \\
\hline & MON87708 probe & $\begin{array}{l}\text { FAM-TCC Cgg ACT TTA gCT CAA AAT } \\
\text { gCA TgT A-BHQ1 }\end{array}$ & 150 & 200 & \\
\hline \multirow[t]{3}{*}{ MON87769 (87 bp) } & MON87769 primer 1 & CAT ACT CAT TgC TgA TCC ATg TAg ATT & 600 & 300 & \multirow{3}{*}{$\begin{array}{l}\text { Mazzara et al. } \\
\text { (2012) }\end{array}$} \\
\hline & MON87769 primer 2 & gCA AgT TgC TCg TgA AgT TTT g & 600 & 300 & \\
\hline & MON87769 probe & $\begin{array}{l}\text { HEX-CCC ggA CAT gAA gCC ATT TAC } \\
\text { AAT TgA C-BHQ1 }\end{array}$ & 200 & 200 & \\
\hline \multirow[t]{3}{*}{ DP-305432 (93 bp) } & DP305-f1 & CgT gTT CTC TTT TTg gCT AgC & 800 & 300 & \multirow{3}{*}{$\begin{array}{l}\text { Mazzara et al. } \\
\text { (2013) }\end{array}$} \\
\hline & DP305-r5 & $\begin{array}{l}\text { gTg ACC AAT gAA TAC ATA ACA CAA } \\
\text { ACT A }\end{array}$ & 500 & 300 & \\
\hline & DP305-p & $\begin{array}{l}\text { HEX-TgA CAC AAA TgA TTT TCA TAC AAA } \\
\text { AgT CgA gA-BHQ1 }\end{array}$ & 220 & 200 & \\
\hline \multirow[t]{3}{*}{ CV127 (88 bp) } & SE-127-f4 & $\begin{array}{l}\text { AAC AgA AgT TTC CgT TgA gCT TTA } \\
\text { AgA C }\end{array}$ & 400 & 300 & \multirow[t]{3}{*}{ Savini et al. (2011) } \\
\hline & SE-127-r2 & CAT TCg TAg CTC ggA TCg TgT AC & 400 & 300 & \\
\hline & SE-127-p3 & $\begin{array}{l}\text { FAM-TTT ggg gAA gCT gTC CCA TgC CC- } \\
\text { BHQ1 }\end{array}$ & 100 & 200 & \\
\hline \multirow[t]{3}{*}{ DAS-68416 (130 bp) } & DAS-68416-4_3f5 & gTA CAT TAA AAA CgT CCg CAA TgT gT & 550 & 300 & \multirow[t]{3}{*}{ Savini et al. (2014) } \\
\hline & DAS-68416-4_3r3 & $\begin{array}{l}\text { gTT TAA gAA TTA gTT CTT ACA gTT TAT } \\
\text { TgT TAg }\end{array}$ & 550 & 300 & \\
\hline & DAS-68416-4_3p3 & $\begin{array}{l}\text { FAM-TTA AgT TgT CTA AgC GTC AAT } \\
\text { A-MGB }\end{array}$ & 150 & 200 & \\
\hline
\end{tabular}

HEX 6-Hexachlorofluorescein, $B H Q 1$ black hole quencher 1, FAM 6-Carboxyfluorescein, MGB minor groove binder side group 


\subsection{Real-time PCR}

The oligonucleotides are described in Table 1. Reactions were carried out using a $1 \mathrm{x}$ QuantiTect Multiplex NoRox PCR Kit (Qiagen, Hilden, Germany) with the primer and probe concentrations given in Table 1. Five $\mu$ l sample DNA or plasmid DNA were added to the final $25 \mu \mathrm{l}$ PCR volume. For amplification the thermal cycling programme used was an initial denaturation step at $95{ }^{\circ} \mathrm{C}$ for $15 \mathrm{~min}$ followed by 45 cycles at $95{ }^{\circ} \mathrm{C}$ for $15 \mathrm{~s}$ and $60{ }^{\circ} \mathrm{C}$ for $60 \mathrm{~s}$. Different real-time PCR instruments were used by the participants (ABI 7500, ABI 7900, Roche LC 480, Roche LC 96, Stratagene MX3005p, BioRad CFX). The probes for detection of GM soy events MON87708, CV-127 and DAS-68416-4 are labelled with FAM, the probes for detection of events MON87701, MON87769 and DP-305423 are labelled with HEX as fluorescent dye.

\subsection{Collaborative trial}

In the collaborative trial, which was organised by the Federal Office of Consumer Protection and Food Safety (Berlin, Germany), 16 experienced German GMO laboratories for seed testing participated. For sample preparation, different mass fractions of certified reference materials were mixed and homogenized before the preparation of the test portions. Each test portion consisted of $200 \mathrm{mg}$ flour filled in $2 \mathrm{ml}$ reaction tubes, which then were sealed with a sealing foil.

Twelve soybean powder samples (Table 2) were provided to the participants. Sample coding was done in a randomized manner. The control plasmid DNAs were supplied by the EURL-GMFF (Ispra, Italy). A dilution buffer (Tris- $\mathrm{HCl}$ with $\mathrm{c}=2 \mathrm{mmol} / \mathrm{l}$; EDTA with $\mathrm{c}=0.2 \mathrm{mmol} / \mathrm{l}$ adjusted to $\mathrm{pH} 8.0 ; 20 \mathrm{ng} / \mu \mathrm{l}$ salmon sperm DNA) was provided for preparing the serial dilutions. Two control plasmid DNAs each should be combined to obtain a mixture of target sequences detected in the FAM and HEX fluorescent channel, respectively. Three plasmid combinations (pMON87701 and pMON87708; pMON87769 and CV127; pDP304423 and DAS-68416) had to be serially diluted to obtain solutions with nominal target sequence copy numbers of $4,2,1,0.4$ and 0.01 copies/ $\mu \mathrm{l}$, respectively. Each level had to be analysed in 6 PCR replicates for POD determination (Uhlig et al. 2015).

Each laboratory received appropriate amounts of lyophilised oligonucleotide primers and probes (Table 1) and a real-time PCR mastermix kit (Qiagen QuantiTect Multiplex NoRox PCR Kit, Hilden,
Table 2 Materials and concentrations of collaborative trial samples

\begin{tabular}{|c|c|c|c|}
\hline Sample no. & $\begin{array}{l}\text { GMO reference material used } \\
\text { for preparation }\end{array}$ & Mass fraction (\%) & $\begin{array}{l}\text { Fluorescence } \\
\text { channel for detection }\end{array}$ \\
\hline \multirow[t]{3}{*}{1} & MON87708 (AOCS 0311-A) & 0.1 & FAM \\
\hline & MON87701 (AOCS 0809-A) & 0.1 & HEX \\
\hline & non-GM soy (AOCS 0906-A) & 99.8 & - \\
\hline \multirow[t]{3}{*}{2} & MON87708 (AOCS 0311-A) & 0.03 & FAM \\
\hline & MON87701 (AOCS 0809-A) & 0.03 & HEX \\
\hline & non-GM soy (AOCS 0906-A) & 99.94 & - \\
\hline \multirow[t]{3}{*}{3} & BPS-CV127-9 (AOCS 0911-C) & 0.1 & FAM \\
\hline & MON87769 (AOCS 0809-B) & 0.1 & HEX \\
\hline & non-GM soy (AOCS 0906-A) & 99.8 & - \\
\hline \multirow[t]{3}{*}{4} & BPS-CV127-9 (AOCS 0911-C) & 0.03 & FAM \\
\hline & MON87769 (AOCS 0809-B) & 0.03 & HEX \\
\hline & non-GM soy (AOCS 0906-A) & 99.94 & - \\
\hline \multirow[t]{2}{*}{5} & DAS-68416-4 (ERM-BF432b) & 0.1 & FAM \\
\hline & non-GM soy (AOCS 0906-A) & 99.9 & - \\
\hline \multirow[t]{2}{*}{6} & DAS-68416-4 (ERM-BF432b) & 0.03 & FAM \\
\hline & non-GM soy (AOCS 0906-A) & 99.97 & - \\
\hline \multirow[t]{2}{*}{7} & DP-305423 (ERM-BF426b) & 0.1 & HEX \\
\hline & non-GM soy (AOCS 0906-A) & 99.9 & - \\
\hline \multirow[t]{2}{*}{8} & DP-305423 (ERM-BF426b) & 0.03 & HEX \\
\hline & non-GM soy (AOCS 0906-A) & 99.97 & - \\
\hline 9-12 & non-GM soy (AOCS 0906-A) & 100 & - \\
\hline
\end{tabular}


Germany). The coded samples and the oligonucleotides were shipped by regular postal mail.

For DNA extractions the laboratories were asked to apply their in-house established method. DNA concentrations of extracts should be determined and adjusted to $40 \mathrm{ng} / \mu \mathrm{l}$. Additionally, it was requested to analyse all flour sample DNAs in one reaction by a soybean taxon-specific real-time PCR (e.g. lectin reference gene specific method according to ISO, 2005).

\subsection{Data analysis}

Statistical data analysis was done by QuoData GmbH (Dresden, Germany) using the software programme PROLab Plus A (Quodata 2015) and their customised statistical concepts. The mathematical-statistical approach and formulas for calculation of the probability of detection (POD) are described (Uhlig et al. 2015).

\section{Results}

The multiplex PCR assay (Table 3) combines six available singleplex real-time PCR methods for eventspecific detections that are not covered by the classical screening strategy of Waiblinger et al. (2010). According to the currently available and validated screening methods, it may also be feasible to detect the soybean events MON8771 and DAS-68416 by including the cry1Ab/Ac and the pat real-time PCR methods.

\subsection{Specificity}

A comprehensive bioinformatics analysis was performed for the multiplex PCR system by the bioinformatics team of the EURL-GMFF to investigate in silico if any interference on the specificity of the multiplex assay can be expected. All primers were analyzed for the probability dimer formation when all primers are included in the same reaction by using the primer3 program (Rozen and Skaletsky 1999). The results are compiled in Table 4 . The primer pair with the highest/worse value of 15.14 is the DAS68416-f5/ MON 87769 primer 1 pair. However, by default primer3 program sets a maximum threshold value for this parameter at 47 , meaning that this highest value is less than a third of what the program considers to be the limit for outright rejecting a primer pair. Therefore, the possibility of dimer formation in the hexaplex PCR is expected to be very low.

In addition, the specificity of the multiplex PCR system was evaluated in silico against 140 plant genomes, selected based on the availability of whole genome sequences. As for the primer dimer assessment, every paired combination of primers was tested against each of the genomes, using custom scripts linked to the e-PCR tool (Schuler 1997), allowing for a maximum of 2 gaps and 2 mismatches per primer and a maximum amplicon size of $500 \mathrm{bp}$. Thirteen potential amplicons were identified, but all have differences in the sequence of the primer binding sites with gaps and mismatches of 7 or above (Table 5). For none of the potential amplicons, a probe binding site could be identified. Therefore, we concluded that the potential of non-specific signals caused by any combination of primers in the multiplex PCR is very low, at least for the 140 plant genomes analysed. Finally, the specificity of the multiplex PCR system was tested by e-PCR against the GMO sequences (authorised and non-authorised) stored in the Central Core Sequence Information System (CCSIS) (Patak 2011), using the same parameters as for the plant genomes. For six GMO sequences, the targets of the event-specific methods are all detected by their respective primer pairs (Table 6). Two unwanted PCR amplifications are predicted where the probes for MON 87708 and MON 87769 perfectly anneal to the corresponding amplicon sequence. Further analyses revealed that two primers, MON87769 primer 1 and MON87708 primer 1, were designed against the same sequence in the T-DNA border region with 20 bp overlap. The technical and practical consequences of the finding that these two primers seem interchangeable between the two methods to which they respectively belong are unclear. However, in the context of detection, it is not expected to affect the specificity of the strategy as the two undesired side products originate from events that are aimed to be detected by the multiplex PCR. Therefore, no unspecific signals by any combination of primers in the hexaplex PCR were predicted for other GM events contained in the CCSIS database.

In the experimental tests with DNA extracted from the GM events carrying the targeted sequences PCRpositive results were obtained with comparable sensitivity. DNAs of other GM soybean events and of other GM crops (e.g. cotton, maize and canola) as well as non-GM DNA from maize, canola, cotton, wheat, rice and potato were tested, but no positive results were observed (Table 7). 
Table 3 Coverage of screening methods for the detection of GM soybean single events (EU 2016; Angers-Loustau et al. 2014; accessed 25 July 2016)

\begin{tabular}{|c|c|c|c|c|c|c|c|c|c|}
\hline \multirow{2}{*}{$\begin{array}{l}\text { GM soybean event } \\
\text { (unique identifier) }\end{array}$} & \multirow{2}{*}{$\begin{array}{l}\text { Country } \\
\text { Decision }^{\mathrm{a}}\end{array}$} & \multirow[b]{2}{*}{$\mathbf{P}-35 S^{b}$} & \multicolumn{4}{|c|}{ Target of screening method } & \multirow[b]{2}{*}{ pat $^{\mathrm{g}}$} & \multirow[b]{2}{*}{$\begin{array}{c}\text { cry1 } \\
\mathbf{A b} / \mathbf{A c} c^{h}\end{array}$} & \multirow[b]{2}{*}{$\begin{array}{c}\text { P- } \\
\text { FMV }^{\mathrm{i}}\end{array}$} \\
\hline & & & T-nos ${ }^{c}$ & $\operatorname{bar}^{d}$ & $\begin{array}{c}\text { ctp2- }^{\text {cp4epsps }} \\
\text { e }\end{array}$ & $\begin{array}{c}\text { P35S- } \\
\text { pat }^{\mathrm{f}}\end{array}$ & & & \\
\hline A2704-12 (ACS-GM005-3) & US & + & - & - & - & + & + & - & - \\
\hline A2704-21 (ACS-GM004-2 & EU & + & - & - & - & + & + & - & - \\
\hline A5547-127 (ACS-GM006-4) & US & + & - & - & - & + & + & - & - \\
\hline A5547-35 (ACS-GM008-6) & EU & + & - & - & - & + & + & - & - \\
\hline CV127 (BPS-CV127-9) ${ }^{\mathrm{j}}$ & EU & - & - & - & - & - & - & - & - \\
\hline DAS-44406-6 (DAS-44406-6) & EU & - & - & - & - & - & + & - & - \\
\hline DAS-68416-4 (DAS-68416-4) & $\mathrm{EU}$ & - & - & - & - & - & + & - & - \\
\hline DAS-81419-2 (DAS-81419-2) & EU & - & - & - & - & - & + & - & - \\
\hline $305423\left(\right.$ DP-305423-1) ${ }^{\mathrm{j}}$ & EU & - & - & - & - & - & - & - & - \\
\hline 356043 (DP-356043-5) & EU & + & - & - & - & - & - & - & - \\
\hline FG72 (MST-FG072-2) & EU & - & + & - & - & - & - & - & - \\
\hline GTS 40-3-2 (MON-04032-6) & EU & + & + & - & - & - & - & - & - \\
\hline GU262 (ACS-GM003-1) & EU & + & - & - & - & + & + & - & - \\
\hline MON87701 (MON-87701-2) & EU & - & - & - & - & - & - & + & - \\
\hline MON87705 (MON-87705-6) & EU & - & - & - & + & - & - & - & + \\
\hline MON87708 (MON-87708-9) & $\mathrm{EU}$ & - & - & - & - & - & - & - & - \\
\hline MON87712 (MON-87712-4) & US & - & - & - & - & - & - & - & - \\
\hline MON87751 (MON-87751-7) & US & - & - & - & - & - & - & - & - \\
\hline MON87754 (MON-87754-1) & Japan & - & - & - & - & - & - & - & - \\
\hline MON87769 (MON-87769-7) & EU & - & - & - & - & - & - & - & - \\
\hline MON89788 (MON-89788-1) & $\mathrm{EU}$ & - & - & - & + & - & - & - & + \\
\hline SYHT0H2 (SYN-000H2-5) & EU & + & + & - & - & + & + & - & - \\
\hline W62 (ACS-GM002-9) & EU & + & + & + & - & - & - & - & - \\
\hline W98 (ACS-GM001-8) & US & + & + & + & - & - & - & - & - \\
\hline 260-05 (DD-026005-3) & EU & + & + & - & - & - & - & - & - \\
\hline
\end{tabular}

Predictions for amplification are indicated by the '+' or '-' symbols. GM events not detected by any screening method or not detected by the original screening set of Waiblinger et al. (2010) are indicated by grey shading

${ }^{\text {a }}$ An authorization decision is taken or is pending

b QT-ELE-00-004 (Bonfini et al. 2012)

c QL-ELE-00-011 (Bonfini et al. 2012)

${ }^{d}$ QL-ELE-00-014 (Bonfini et al. 2012)

e QL-CON-00-008 (Bonfini et al. 2012)

${ }^{f}$ QL-CON-00-011 (Bonfini et al. 2012)

g QT-ELE-00-002 (Bonfini et al. 2012)

h QL-ELE-00-016 (Bonfini et al. 2012)

i QL-ELE-00-015 (Bonfini et al. 2012)

J Not detected by any screening method

\subsection{Assay design and optimisation}

If FAM is the only dye for probe fluorescent labelling, the multiplex PCR assay requires at least six independent positive control reactions. Therefore, the original EURL-GMFF protocol that uses FAM as reporter dye and Carboxytetramethylrhodamine (TAMRA) as fluorescence quencher was modified. The MON 87701, MON 87769 and DP-305423 probes were labelled with HEX as fluorescent dye, the MON 87708, CV-127 and DAS-68416 probes remained FAM-labelled. Thereby, positive control DNAs for two GM events (detected by 
Table 4 Probability values for primer-dimer formation (Rozen and Skaletsky 1999)

\begin{tabular}{|c|c|c|c|c|c|c|c|c|c|c|c|c|}
\hline & SE-127-r2 & SE-127-f4 & $\begin{array}{l}\text { MON87708 } \\
\text { primer } 2\end{array}$ & $\begin{array}{l}\text { MON87708 } \\
\text { primer } 1\end{array}$ & $\begin{array}{l}\text { MON } \\
87769 \\
\text { primer } 2\end{array}$ & $\begin{array}{l}\text { MON } \\
87769 \\
\text { primer } 1\end{array}$ & $\begin{array}{l}\text { MON } \\
87701 \\
\text { primer } 2\end{array}$ & $\begin{array}{l}\text { MON } \\
87701 \\
\text { primer } 1\end{array}$ & DP305-r5 & DP305-f1 & $\begin{array}{l}\text { DAS- } \\
68416-r 3\end{array}$ & $\begin{array}{l}\text { DAS- } \\
68416-f 5\end{array}$ \\
\hline DAS-68416-f5 & 8.32 & 0 & 0 & 4.85 & 1.34 & 15.14 & 0 & 0 & 0 & 0 & 0 & 9.40 \\
\hline DAS-68416-r3 & 0 & 0 & 2.19 & 0 & 0 & 0 & 0 & 0 & 2.58 & 0 & 0 & - \\
\hline DP305-f1 & 0 & 0 & 4.79 & 0 & 0 & 0 & 0 & 0 & 0.44 & 6.04 & - & - \\
\hline DP305-r5 & 0 & 0 & 0 & 0 & 0 & 0 & 0 & 0 & 3.75 & - & - & - \\
\hline $\begin{array}{c}\text { MON } 87701 \\
\text { primer } 1\end{array}$ & 0 & 0 & 0 & 0 & 0 & 0 & 0 & 0 & - & - & - & - \\
\hline $\begin{array}{c}\text { MON } 87701 \\
\text { primer } 2\end{array}$ & 0 & 0 & 0 & 0 & 0 & 8.91 & 14.63 & - & - & - & - & - \\
\hline $\begin{array}{c}\text { MON } 87769 \\
\text { primer } 1\end{array}$ & 0 & 0 & 0 & 0 & 0 & 0.49 & - & - & - & - & - & - \\
\hline $\begin{array}{c}\text { MON } 87769 \\
\text { primer } 2\end{array}$ & 0 & 0 & 0 & 0 & 5.55 & - & - & - & - & - & - & - \\
\hline $\begin{array}{c}\text { MON87708 } \\
\text { primer } 1\end{array}$ & 0 & 0 & 0 & 0 & - & - & - & - & - & - & - & - \\
\hline $\begin{array}{r}\text { MON87708 } \\
\text { primer } 2\end{array}$ & 0 & 0 & 0 & - & - & - & - & - & - & - & - & - \\
\hline SE-127-f4 & 0.78 & 10.27 & - & - & - & - & - & - & - & - & - & - \\
\hline SE-127-r2 & 0 & - & - & - & - & - & - & - & - & - & - & - \\
\hline
\end{tabular}

For interpretation of the values, see chapter 3.1

Table 5 Potential amplicons identified by the e-PCR tool (Schuler 1997)

\begin{tabular}{|c|c|c|c|c|c|c|}
\hline $\begin{array}{l}\text { Hit } \\
\text { number }\end{array}$ & Primer 1 & Primer 2 & Species & $\begin{array}{l}\text { Mismatches/ } \\
\text { gaps }\end{array}$ & $\begin{array}{l}\text { Amplicon } \\
\text { size }\end{array}$ & $\begin{array}{l}\text { Probe } \\
\text { binding }\end{array}$ \\
\hline 1 & DP305-f1 & MON87708 primer 1 & Actinidia chinensis (kiwi) & $4 / 4$ & 216 & No \\
\hline 2 & DP305-f1 & MON87708 primer 1 & Beta vulgaris (beet) & $3 / 4$ & 72 & No \\
\hline 3 & DP305-f1 & MON87708 primer 1 & $\begin{array}{l}\text { Capsicum annuum (chili } \\
\text { pepper) }\end{array}$ & $3 / 4$ & 496 & No \\
\hline 4 & MON 87769 primer 2 & MON87708 primer 1 & Nicotiana otophora & $3 / 6$ & 488 & No \\
\hline 5 & MON 87769 primer 2 & MON87708 primer 1 & $\begin{array}{l}\text { Nicotiana sylvestris } \\
\text { (woodland tobacco) }\end{array}$ & $5 / 2$ & 352 & No \\
\hline 6 & MON87708 primer 1 & MON87708 primer 1 & $\begin{array}{l}\text { Brachypodium } \\
\text { distachyon (false } \\
\text { brome) }\end{array}$ & $4 / 4$ & 89 & No \\
\hline 7 & MON87708 primer 1 & MON87708 primer 1 & Hordeum vulgare (barley) & $1 / 7$ & 79 & No \\
\hline 8 & MON87708 primer 1 & MON87708 primer 1 & $\begin{array}{l}\text { Setaria italica (foxtail } \\
\text { millet) }\end{array}$ & $4 / 4$ & 67 & No \\
\hline 9 & MON87708 primer 1 & MON87708 primer 1 & $\begin{array}{l}\text { Elaeis guineensis (African } \\
\text { oil palm) }\end{array}$ & $4 / 5$ & 477 & No \\
\hline 10 & MON87708 primer 1 & MON87708 primer 1 & Gossypium raimondii & $4 / 4$ & 143 & No \\
\hline 11 & MON87708 primer 1 & MON87708 primer 1 & $\begin{array}{l}\text { Manihot esculenta } \\
\quad \text { (manioc) }\end{array}$ & $2 / 8$ & 474 & No \\
\hline 12 & MON87708 primer 1 & MON87708 primer 1 & $\begin{array}{l}\text { Manihot esculenta } \\
\quad \text { (manioc) }\end{array}$ & $2 / 8$ & 397 & No \\
\hline 13 & MON87708 primer 1 & MON87708 primer 1 & $\begin{array}{l}\text { Nicotiana } \\
\text { tomentosiformis }\end{array}$ & $4 / 4$ & 557 & No \\
\hline
\end{tabular}

a FAM and HEX signal) can be analysed in one reaction. Furthermore, in case of a positive finding for a sample DNA, the subsequent analysis for identification is less complex if only a FAM or HEX signal is detected.
For multiplex PCR analyses with at least two dyes, the use of non-fluorescent quenchers (e.g. Black Hole Quencher for TaqMan probes) is recommended instead of the TAMRA fluorescent quencher. 
Table 6 Specificity assessment against the CCSIS GMO sequence database (Patak 2011)

\begin{tabular}{lllllll}
\hline Hit & Primer 1 & Primer 2 & GM event & Mismatches/gaps & Amplicon size & Probe binding \\
\hline 1 & DAS-68416-f5 & DAS-68416-r3 & DAS-68416 & $0 / 0$ & 130 & Yes \\
2 & DP305-f1 & DP305-r5 & DP-305423 & $0 / 0$ & 93 & Yes \\
3 & MON 87701 primer 1 & MON 87701 primer 2 & MON 87701 & $0 / 0$ & 89 & Yes \\
4 & MON 87769 primer 1 & MON87708 primer 2 & MON 87708 & $0 / 0$ & 90 & Yes \\
5 & MON 87769 primer 1 & MON 87769 primer 2 & MON 87769 & $0 / 0$ & 87 & Yes \\
6 & MON87708 primer 1 & MON 87769 primer 2 & MON 87769 & $0 / 0$ & Yes & Yes \\
7 & MON87708 primer 1 & MON87708 primer 2 & MON 87708 & $0 / 0$ & 88 & Yes \\
8 & SE-127-f4 & SE-127-r2 & CV-127 & $0 / 0$ & & 88 \\
\hline
\end{tabular}

Table 7 Specificity data for the multiplex PCR assay

\begin{tabular}{|c|c|c|}
\hline GM plant & $\begin{array}{l}\text { In silico sequence } \\
\text { identity }^{\mathrm{a}}\end{array}$ & $\begin{array}{l}\text { Experimenta } \\
\text { confirmation }\end{array}$ \\
\hline MON87701 & + & + \\
\hline MON87708 & + & + \\
\hline MON87769 & + & + \\
\hline DP-305423 & + & + \\
\hline CV-127 & + & + \\
\hline DAS-68416 & + & + \\
\hline A2704-12 & - & - \\
\hline A5547-127 & - & - \\
\hline GTS40-3-2 & - & - \\
\hline DP-356043 & - & - \\
\hline FG72 & - & - \\
\hline MON89788 & - & - \\
\hline MON87705 & - & - \\
\hline MON531 & - & - \\
\hline MON810 & - & - \\
\hline DAS-59122 & - & - \\
\hline NK603 & - & - \\
\hline TC-1507 & - & - \\
\hline Bt11 & - & - \\
\hline GT73 & - & - \\
\hline Non-GM maize & - & - \\
\hline Non-GM canola & - & - \\
\hline Non-GM cotton & - & - \\
\hline Non-GM wheat & - & - \\
\hline Non-GM rice & - & - \\
\hline Non-GM potato & - & - \\
\hline
\end{tabular}

a Tests using e-PCR analysis (Schuler 1997)

Therefore, BHQ1 was used as a quencher for analyses with five probes. For the DAS-68416 PCR system a MGB probe was used.

The primer and probe concentrations in the reaction setup for both singleplex PCR and multiplex assays are outlined in Table 2 . To simplify the multiplex assay reaction set-up, the primer-probe final concentrations for the multiplex assay were standardised to $0.3 \mu \mathrm{M}$ for the forward and reverse primers and to $0.2 \mu \mathrm{M}$ for the probes according to the recommendation of the multiplex PCR master mix producer (Qiagen 2011).

\subsection{Robustness}

Six different real-time PCR cycler brands or models were used by the different laboratories in this collaborative study. No specific difficulties or unusual observations were reported or identified in the evaluation of the results indicating the methods robustness to different real-time PCR cyclers.

\subsection{Collaborative trial}

The collaborative trial for validation of the multiplex real-time PCR assay was designed according to internationally accepted guidelines (Horwitz 1995; ISO 1994) and carried out in 2015. It included the DNA extraction in order to evaluate the effect of this analysis step. A set of 12 coded soybean powder samples (Table 2), six control plasmid DNAs for preparation of a dilution series and all required reagents were sent to 16 participating laboratories. For convenience, the nominal copy number of the control plasmid DNA solutions as specified by the EURL-GMFF $(2000$ copies/ $\mu \mathrm{l}$ ) was communicated to the participants. All laboratories returned results within the given time frame.

For the DNA extraction the laboratories were asked to use their routine method and to adjust the DNA extract to a final concentration of $40 \mathrm{ng} / \mu \mathrm{l}$. Each DNA extract had to be tested in duplicate with the multiplex PCR. In addition, the sample DNAs had to be analysed using a soybean taxon-specific real-time 
PCR. An average $\mathrm{C}_{\mathrm{q}}$ value of $22.8 \pm 2.4$ (range of 19.1-28.0) was measured for the extracted DNAs.

Results from one laboratory were not included in the evaluation because identical $\mathrm{C}_{\mathrm{q}}$ values for HEX and FAM were reported. It turned out that the realtime PCR device was not working correctly in terms of FAM and HEX fluorescence separation. Four laboratories using the $A B I 7500$ instrument reported unusual high absolute fluorescence values for FAM and HEX. The specifications for this instruments recommend the use of ROX as a passive reference dye for normalisation of fluorescence values. The laboratories remarked that a mastermix with ROX and lower concentrations of the TaqMan probes would possibly improve the performance of the multiplex assay.

\subsection{False-positive and false-negative rates}

The PCR results for FAM and HEX reported by 15 laboratories were taken into calculation of the falsenegative and false-positive rates (Table 8). Six samples contained either one or no GM soybean event, respectively (Table 2). Hence, for 360 PCR analyses a negative result was expected for FAM and/or HEX. Eight samples contained material of either one or two different GM events (Table 1, number 1 to 8), which also accounts for 360 PCR reactions in total with an expected positive result for FAM and/or HEX. In summary, 14 PCR results for GM-positive samples were classified as negative. Ten of these false-negative results were obtained in two laboratories for samples with a $0.03 \%(\mathrm{~m} / \mathrm{m})$ content of the respective $\mathrm{GM}$ event. These laboratories reported high $\mathrm{C}_{\mathrm{q}}$ values (in average 26.0 and 28.0, respectively) for the

Table 8 Collaborative trial study results

\begin{tabular}{ll}
\hline Number of laboratories & 16 \\
Number of laboratories submitting results & 16 \\
Number of laboratories considered for the evaluation & 15 \\
Number of DNA samples per laboratory & 12 \\
Number of evaluated PCR results & \\
Total & 720 \\
PCR results with GM-positive samples & 360 \\
PCR results with GM-negative samples & 360 \\
Number of false negative results with 0.1\% (m/m) & 4 \\
GM-positive samples & \\
Number of false negative results with 0.03\% (m/m) & 10 \\
GM-positive samples & \\
False negative rate & $3.9 \%$ \\
Number of false positive results & 1 \\
False positive rate & $0.3 \%$ \\
\hline
\end{tabular}

corresponding soybean taxon-specific PCR. Thus, PCR inhibition or an incorrect DNA quantification most likely caused these results.

A single false-positive PCR result was obtained for a non-GM soybean sample (Cq values of 39.8 ). The laboratory was asked to repeat the PCR analysis of this sample DNA and they could not verify this positive result.

\subsection{Probability of detection (POD)}

Serial dilutions of the plasmid mixtures each containing a FAM- and a HEX-detectable target sequence, were analysed in six replicates per level. Nominal copy numbers in the range of 20 to 0.1 copies per PCR reaction were analysed. The 20 copies level was analysed in parallel to the unknown soybean samples and thereby served as positive control in this PCR run. The other five levels (10, 5, 2, 1 and 0.1 copies per PCR) were analysed in a second PCR run. In total, each participant submitted 216 PCR results (36 for each target sequence). The results reported by the laboratories are compiled in Table 9. Three laboratories reported difficulties and failure to detect DAS-68416 in this PCR run. It turned out that the MGB probe used for this PCR system caused the problem, because a replaced probe restored detection of DAS-68416 (laboratory E).

An unexpected high frequency of negative PCR results for the low copy number levels (5 to 1 copy) was reported. Due to this observation, the copy numbers of the control plasmids were verified by digital PCR after the collaborative trial. Considerably lower copy number estimates for all six control plasmids were observed (Table 10).

A statistical analysis based on modelling the POD was performed based on the test result compiled in Table 9 (Uhlig et al. 2015). Before calculating the ratios of positive and negative PCR results, the underlying copy numbers were corrected according to the digital PCR estimates (Table 10). The slope parameter $b$ for the POD curves between laboratories showed no significant deviations and the other POD parameter were therefore calculated with an assumed value of $b=1$. The statistical analysis showed values for the $\mathrm{LOD}_{95 \%}$ ranging between three and five copies (Table 11). For the associated interlaboratory standard deviation $\sigma \mathrm{L}$ the results are within the recommended performance limits for qualitative real-time PCR methods. An $\sigma \mathrm{L}$ value of 1 corresponds to an $\mathrm{LOD}_{95 \%}$ of $\sim 20$ copies, which is defined as the lowest copy number that should be detected according to the recommendations of the German § 64 LFGB working group (BVL 2016). Note 


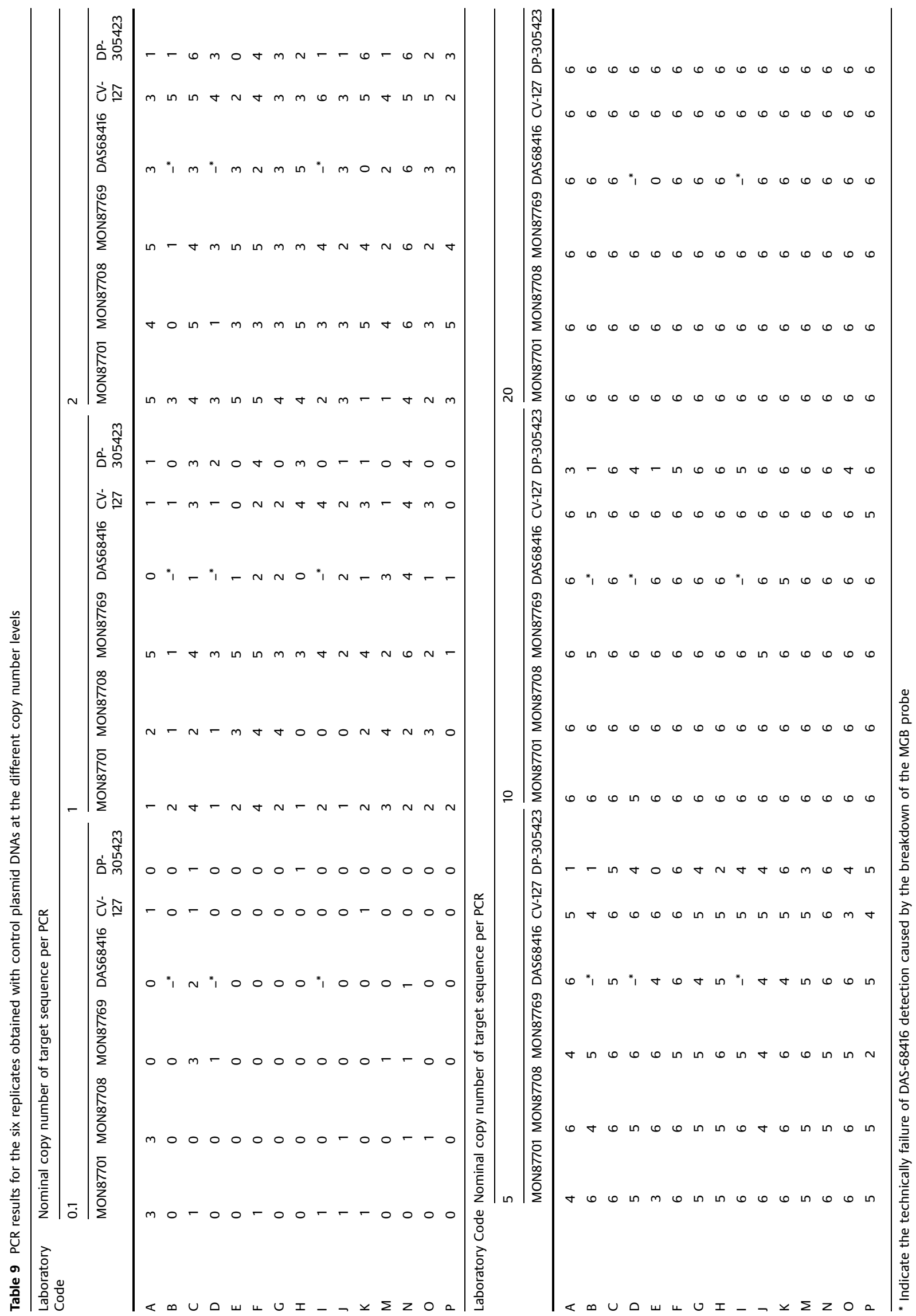


Table 10 Copy number estimates for the control plasmid DNA solutions obtained by digital PCR determinations

\begin{tabular}{|c|c|c|c|c|c|c|c|}
\hline \multirow[t]{2}{*}{ Control plasmid (GM soy event) } & \multirow{2}{*}{$\begin{array}{l}\text { Digital PCR copy } \\
\text { number/ } \mu \text { l (SD) }\end{array}$} & \multicolumn{6}{|c|}{ Corrected estimates at copy number level } \\
\hline & & 20 & 10 & 5 & 2 & 1 & 0.1 \\
\hline pENGL-00-05/09-01 (MON 87701) & $971( \pm 56)$ & 9.71 & 4.86 & 2.42 & 0.97 & 0.49 & 0.05 \\
\hline pENGL-00-02/11-01 (MON 87708) & $973( \pm 103)$ & 9.73 & 4.87 & 2.43 & 0.97 & 0.49 . & 0.05 \\
\hline pENGL-00-07/09-01 (MON 87769) & $1079( \pm 54)$ & 10.79 & 5.40 & 2.70 & 1.08 & 0.54 & 0.05 \\
\hline pENGL-00-07/07-01 (DP-305423) & $663( \pm 66)$ & 6.63 & 3.32 & 1.66 & 0.66 & 0.33 & 0.03 \\
\hline pENGL-00-01/09-01 (CV-127) & $977( \pm 50)$ & 9.77 & 4.89 & 2.44 & 0.98 & 0.49 & 0.05 \\
\hline pENGL-00-05/09-01 (DAS-68416) & $1250( \pm 78)$ & 12.5 & 6.25 & 3.13 & 1.25 & 0.63 & 0.06 \\
\hline
\end{tabular}

Table $11 P O D$ statistics for the multiplex PCR assay

\begin{tabular}{|c|c|c|c|c|c|c|}
\hline \multirow[t]{2}{*}{ Parameter } & \multicolumn{6}{|c|}{ Value for PCR system } \\
\hline & MON87701 & MON87708 & MON87769 & DAS-68416 & CV-127 & DP-305423 \\
\hline Number of laboratories & 15 & 15 & 15 & 12 & 15 & 15 \\
\hline $\begin{array}{l}\text { PCR replicates per concentration level } \\
\text { and laboratory }\end{array}$ & 6 & 6 & 6 & 6 & 6 & 6 \\
\hline \multicolumn{7}{|l|}{ POD curve } \\
\hline Average amplification probability $\lambda_{0}$ & 0.90 & 0.93 & 0.80 & 0.58 & 0.89 & 0.69 \\
\hline $\begin{array}{l}95 \% \text { confidence interval for the } \\
\text { estimated value of } \lambda_{0}\end{array}$ & $0.67-1.08$ & $0.76-1.16$ & $0.62-1.06$ & $0.45-0.77$ & $0.71-1.13$ & $0.43-1.10$ \\
\hline Slope $b$ & 1 & 1 & 1 & 1 & 1 & 1 \\
\hline $\begin{array}{l}\text { Laboratory standard deviation } \sigma_{\mathrm{L}} \\
\text { LOD }_{95 \%} \text { (in copies) }\end{array}$ & 0.10 & 0.25 & 0.40 & 0.30 & 0.30 & 0.81 \\
\hline For the median laboratory & 3.3 & 3.2 & 3.7 & 5.1 & 3.4 & 4.4 \\
\hline
\end{tabular}

For each of the six event-specific real-time PCR systems the estimates for the average amplification probability $\left(\lambda_{0}\right)$ and its $95 \%$ confidence interval, the slope of the $P O D$ curve $(b)$ relative to the ideal $P O D$ curve $(b=1)$, the laboratory standard deviation $\left(\sigma_{\mathrm{L}}\right)$ and the $\mathrm{LOD}_{95 \%}$ (number of copies of the target sequence at $P O D=0.95$ ) for the median laboratory (laboratory with average amplification probability) are given

that the DP-305423 PCR system showed the poorest performance for the different POD parameters.

\section{Discussion}

\subsection{Assay design and optimisation}

The study demonstrates that setting up a multiplex PCR assay for GMO screening based on the combination of established event-specific real-time PCR methods is feasible. Based on the experiences from both development and validation of the study results, several aspects are important to be considered for such multiplex assay design and optimisation. At first, comprehensive bioinformatics testing is required concerning primer-dimer formation, specificity to GMO and plant sequences or unspecific amplifications caused by unwanted primer combinations and/or probe binding (Rozen and Skaletsky 1999; Schuler 1997). All single event-specific PCR methods are evaluated by the EURL-GMFF for the experimental specificity assessment according to the ENGL minimum performance requirements (ENGL 2015). Therefore, it is appropriate not to repeat all specificity tests for the multiplex system, as this would go beyond the scope of validation.

We recommend to ensure that all PCR modules that are included in a multiplex assay have optimal performance. If a module is only moderately performing as singleplex PCR, it will most likely cause problems in a multiplex PCR, particularly for sensitivity. The use of a real-time PCR mastermix compatible for multiplex assays is another important prerequisite for proper functioning. Several different brands are available and the developer and user should essentially consider the specifications and requirements of the applied real-time PCR instrument before choosing a certain mastermix, for example, the use of ROX as a passive reference dye for normalisation of fluorescence signals is recommended for specific instrument brands, but it is 
optional for instruments from other suppliers. In general, we assumed that the ROX dye should be omitted for multi-color multiplex assays in order to minimize fluorescence background noise.

Other dye combinations from FAM and HEX may be applicable. The selected dyes need to be compatible with interference-free duplex PCR analysis and the detection optics of the routinely used real-time PCR cycler. For optimal results, it is recommended to choose combinations of dyes without any spectral overlap caused by wide fluorescence emission profiles.

Currently, only a few guidelines exist for the development, setup and validation of multiplex PCR assays. It is suggested that changes to already approved assays (such as inclusion of a new target) can be applied by testing subsets in order to confirm the performance, rather than requiring the full range of validation to be repeated (ENGL 2015; NRC and IOM 2015). The asymmetric LOD (LOD asym) should be determined for multiplex qualitative PCR modules according to the ENGL guidance document (ENGL 2015). It is defined as a performance parameter for the sensitivity of a multiplex assay when one target is present at very low concentration in comparison with the other targets at high concentration (Huber et al. 2013; Broeders et al. 2014). However, for the multiplex assay the competitive effects between target amplifications are not relevant, because any positive PCR signal must be verified by singleplex identification tests for all respective targets. The important parameters and possible requirements for multiplex assay optimisation are compiled and several recommendations are provided (Table 12). In summary, our validation

Table 12 Relevant parameters for multiplex real-time PCR assay optimisation

\begin{tabular}{|c|c|c|}
\hline Parameter & Optimisation & Modification \\
\hline Primer concentration & Yes & Reduced concentration \\
\hline Probe concentration & Yes & Reduced concentration \\
\hline Probe labelling & Yes & $\begin{array}{l}\text { Reporter dyes adapted to } \\
\text { available fluorescent } \\
\text { channels; use of non- } \\
\text { fluorescent quencher }\end{array}$ \\
\hline $\begin{array}{l}\text { Temperature-time- } \\
\text { program }\end{array}$ & No & $\begin{array}{l}\text { Adapted to multiplex PCR } \\
\text { mastermix }\end{array}$ \\
\hline Master mix & Yes & $\begin{array}{l}\text { Appropriate for multiplex } \\
\text { PCR (without ROX) }\end{array}$ \\
\hline Specificity & Yes & Bioinformatic verification \\
\hline $\begin{array}{l}\text { Real-time PCR } \\
\text { machine }\end{array}$ & Yes & $\begin{array}{l}\text { Fluorescent filter } \\
\text { adjustment }\end{array}$ \\
\hline
\end{tabular}

study shows that the setup of a multiplex assay for event-specific screening appears reasonable and can be applied without an unacceptable loss of sensitivity.

\subsection{Interpretation of analysis results}

The multiplex assay has to be applied as a twostage GMO analysis with an initial screening test followed by GM event identification using the respective singleplex PCR assay, if a positive result is obtained in the screening stage. In situations with strong FAM or HEX signals and a corresponding low $\mathrm{C}_{\mathrm{q}}$ value, the singleplex identification tests for all GM events should be performed in order to ensure that the detection of targeted events at a comparable lower level is not missed due to competitive effects.

\subsection{Modularity of multiplex assays}

According to the EUginius method verification table (EU 2016), seven GM soybean events (CV-127, DP305423, MON 87708, MON 87712, MON 87751, MON 87754 and MON 87769) are currently not detected by any of the common element and/or construct-specific reference methods (see Table 3). We propose that the format of the multiplex assay should apply also to other GM soybean events. Removing or exchanging an event-specifc PCR module system may be required if

(a) The GM event is frequently present in specific food/feed matrices and

(b) Traces of the GM event are expected because the cultivation of the GMO has drastically increased (e.g. as lately observed for soybean event MON 87701).

It should be feasible to include another novel and emerging GM soybean event into the multiplex assay without complex optimisation and validation. A prerequisite will be the bioinformatics analyses concerning the specificity, which allows the prediction of cross-reactivity or unspecific amplification products.

Apart from soybean powder, so far the multiplex assay was not tested for other soybean products containing these GM events. It is applicable for seed samples or pure and raw soybean products. More experimental data from routine testing of real-life samples taken from complex matrices and composite food and feed products will gain information on the assay applicability and any unpredictable matrix effects. 


\section{Conclusion}

The results of the study show that the event-specific multiplex real-time PCR assay is capable of detecting GM soybean events at a mass fraction of down to $0.03 \%$ with an acceptable false-negative rate. A relative GM soybean content of $0.1 \%$ was detected by all laboratories, if sufficient high quality DNA was added to the multiplex PCR. The method is transferable to other laboratories and fit-for-purpose to test for the presence of six different soybean events in raw material such as flour grinded from seed lots.

The approach combines event-specific PCR methods within one multiplex assay for GMO screening and should be applicable to other crops e.g. GM maize. When searching in relevant databases, currently four maize GM events (LY038, DAS-40278, VCO01981 and BVLA-430101) are not detected by the screening strategy and methods set as given in Table 3 (Angers-Loustau et al. 2014; EU 2016). The development and validation of a similar maize eventspecific multiplex PCR assay is planned in near future.

Acknowledgements The authors are grateful to Beate Mühlbauer (BVL) for the technical assistance and Jens Tomala (BVL) for his constant organisational support during this study. We would like to thank Joachim Bendiek (BVL) for carefully reading the manuscript and for helpful comments. The authors are also grateful to all participants of the collaborative trial: Ottmar Goerlich (Bayerisches Landesamt für Gesundheit und Lebensmittelsicherheit, Oberschleißheim); Kathrin Lieske (Bundesamt für Verbraucherschutz und Lebensmittelsicherheit, Berlin); Claudia Brünen-Nieweler (Chemisches und Veterinäruntersuchungsamt Münsterland-Emscher-Lippe, Münster); Klaus Pietsch (Chemisches und Veterinäruntersuchungsamt, Freiburg); Dörte Wulff (Eurofins Genscan Analytics GmbH, Freiburg); Gabriele Näumann (Institut für Hygiene und Umwelt, Hamburg); Anke Belter (Landesamt für Umweltschutz Sachsen-Anhalt, Halle); Karl Woll (Landesamt für Verbraucherschutz, Saarbrücken); Thomas Richter (Landeslabor Berlin Brandenburg, Berlin); Ralf Reiting (Landesbetrieb Hessisches Landeslabor, Kassel); Britgitte Speck (Landwirtschaftliches Technologiezentrum Augustenberg, Karlsruhe); Ole Sindt (Lebensmittel- und Veterinäruntersuchungsamt, Neumünster); Heike Naumann (Niedersächsisches Landesamt für Verbraucherschutz und Lebensmittelsicherheit, Braunschweig); Michael Kleine (Planton GmbH, Kiel); Karsten Westphal (Staatliche Betriebsgesellschaft für Umwelt und Landwirtschaft, Nossen); Sabine Domey (Thüringer Landesanstalt für Landwirtschaft, Jena).

\section{Compliance with ethical standards}

Conflict of interest The authors declare that they have no conflict of interest.
Ethical approval This article does not contain any studies with human participants or animals performed by any of the authors.

Informed consent Not applicable.

Open Access This article is distributed under the terms of the Creative Commons Attribution 4.0 International License (http://creativecommons.org/licenses/by/4.0/), which permits unrestricted use, distribution, and reproduction in any medium, provided you give appropriate credit to the original author(s) and the source, provide a link to the Creative Commons license, and indicate if changes were made.

\section{References}

Angers-Loustau A, Petrillo M, Bonfini L, Gatto F, Rosa S, Patak A, Kreysa J (2014) JRC GMO-Matrix: a web application to support Genetically Modified Organisms detection strategies. BMC Bioinformatics 15:6592

Anonymous (2016) Danube Soya Association. ahttp://www. donausoja.org/en. Accessed 25 July 2016

Bahrdt C, Krech A, Wurz A, Wulff D (2010) Validation of a newly developed hexaplex real-time PCR assay for screening for presence of GMOs in food, feed and seed. Anal Bioanal Chem 396:2103-2112

BCH (2016) Living Modified Organism (LMO) Registry. http:// bch.cbd.int/database/lmo-registry/. Accessed 27 Sep 2016

Bonfini L, van den Bulcke MH, Mazzara M, Ben E, Patak A (2012) GMOMETHODS: The European Union Database of Reference Methods for GMO Analysis. J AOAC Internat 95:1713-1719

Broeders S, Huber I, Grohmann L, Berben G, Taverniers I, Mazzara M, Roosens N, Morisset D (2014) Guidelines for validation of qualitative real-time PCR methods. Trends Food Sci Technol 37:115-126

BVL (2016) Guidelines for the validation of qualitative real-time PCR methods by means of a collaborative study. http:// www.bvl.bund.de/SharedDocs/Downloads/09_ Untersuchungen/Guidelines\%20for\%20the\%20validation\% 20of\%20qualitative.pdf?_blob=publicationFile\&v=2. Accessed 26 July 2016

CEN (2014) Technical Specification CEN/TS 16707:2014 Foodstuffs-Methods of analysis for the detection of genetically modified organisms and derived products-Polymerase chain reaction (PCR) based screening strategies

Charels D, Mazzara M, Grazioli E, Van den Eede G (2011) Eventspecific method for the quantification of soybean line MON87701 using real-time PCR-validation report and protocol. Online publication. doi:10.2788/38101

De Visser CLM, Schreuder R, Stoddard F (2014) The EU's dependency on soya bean import for the animal feed industry and potential for EU produced alternatives. Oilseeds Fats Crops Lipids. doi:10.1051/ocl/2014021

Dorries HH, Remus I, Gronewald A, Gronewald C, BerghofJager K (2010) Development of a qualitative, multiplex real-time PCR kit for screening of genetically modified organisms (GMOs). Anal Bioanal Chem 396:2043-2054

ENGL (2015) Definition of minimum performance requirements for analytical methods of GMO testing. European Network of GMO Laboratories (ENGL). http://gmo-crl.jrc. ec.europa.eu/doc/MPRReportApplication20_10_2015.pdf. Accessed 25 July 2016 
EU (2003) Regulation (EC) No. 1829/2003 of the European Parliament and of the Council of 22 September 2003 on genetically modified food and feed. OJE 268:1-23

EU (2016) EU Register of authorized GMOs. http://ec.europa.eu/ food/dyna/gm_register/index_en.cfm. Accessed 27 Sep 2016

EUginius (2016) European GMO Initiative for a Unified database System. http://www.euginius.eu. Accessed 25 July 2016

Gerdes L, Busch U, Pecoraro S (2012) GMOfinder-A GMO Screening Database. Food Anal Methods 5:1368-1376

Horwitz W (1995) Protocol for the design, conduct and interpretation of method performance studies. Pure Appl Chem 1995(67):331-343

Huber I, Block A, Sebah D, Debode F, Morisset D, Grohmann L, Berben G, Stebih D, Milavec M, Zel J, Busch U (2013) Development and validation of duplex, triplex, and pentaplex real-time PCR screening assays for the detection of genetically modified organisms in food and feed. J Agric Food Chem 61:10293-10301

ISO (1994) ISO 5725-2 Accuracy (trueness and precision) of measurement methods and results-part 2: Basic method for the determination of repeatability and reproducibility of a standard measurement method

Köppel R, van Velsen F, Felderer N, Bucher T (2012) Multiplex real-time PCR for the detection and quantification of DNA from four transgenic soy Mon 89788, A5547-127, Roundup Ready, A2704-12 and lectin. Eur Food Res Technol 235:23-28

Köppel R, Bucher T, Meuwly A, Moor D (2014) Multiplex realtime PCR Method for the detection and quantification of DNA from the four transgenic soy traits DP-356043-5, DP305423-1, MON 87701, and BPS-CV127-9 and lectin. Eur Food Res Technol 239:347-355

Mazzara M, Charles-Delobel C, Pinski G, Savini C, Van den Eede G (2012) Event-specific method for the quantification of soybean MON87769 using real-time PCR-validation report and validated method. JRC Sci Tech Res Rep. doi:10.2788/ 4544

Mazzara M, Munaro B, Grazioli E, Savini C, Charles-Delobel C, Van Den Eede G (2013) Event-specific method for the quantification of soybean event DP-305423-1 using realtime PCR v. 1.01-validation report and validated method. JRC Sci Tech Res Rep. doi:10.2788/21515

NRC and IOM (2015) National Research Council and Institute of Medicine. BioWatch PCR Assays: Building Confidence, Ensuring Reliability. The National Academies Press, Washington, DC
Patak A (2011) CCSIS specialist EMBnet node: AGM2011 report. EMBnet.journal 17:13-14

Qiagen (2011) QuantiTect Multiplex PCR Handbook. https:// www.qiagen.com/de/resources/download.aspx?id= 1ff92f33-6f50-4b9b-9b73-3806f5f0766a\&lang=en. Accessed 25 July 2016

Quodata (2015) PROLab software for PT programs and collaborative studies. http://quodata.de/en/software/forinterlaboratory-tests.html. Accessed 27 July 2016

Rozen S, Skaletsky H (1999) Primer3 on the WWW for general users and for biologist programmers. In: Miesener $S$, Krawetz SA (eds) Bioinformatics methods and protocols. Humana Press, Totowa, pp 365-386

Savini C, Mazzara M, Pinski G, Van den Eede G (2011) Eventspecific method for the quantification of soybean CV127 using real-time PCR-validation report and protocol. JRC Sci Tech Res Rep. doi:10.2788/37626

Savini C, Mazzara M, Munaro B, Kreysa J (2013) Event-specific method for the quantification of soybean MON87708 using real-time PCR-validation report and validated method. JRC Sci Tech Res Rep. doi:10.2788/90943

Savini C, Sacco MG, Mazzara M, Kreysa J (2014) Event-specific method for the quantification of soybean DAS-68416-4 using real-time PCR. validation report and validated method. JRC Sci Tech Res Rep. doi:10.2788/87396

Scholtens I, Laurensse E, Molenaar B, Zaaijer S, Gaballo H, Boleij P, Bak A, Kok E (2013) Practical experiences with an extended screening strategy for genetically modified organisms (GMOs) in real-life samples. J Agric Food Chem 61:9097-9109

Schuler GD (1997) Sequence mapping by electronic PCR. Genome Res 7:541-550

Uhlig S, Frost K, Colson B, Simon K, Maede D, Reiting R, Gowik P, Grohmann L (2015) Validation of qualitative PCR methods on the basis of mathematical-statistical modelling of the probability of detection. Accred Qual Assur 20:75-83

Waiblinger HU, Ernst B, Anderson A, Pietsch K (2008) Validation and collaborative study of a P35S and T-nos duplex real-time PCR screening method to detect genetically modified organisms in food products. Eur Food Res Technol 226:1221-1228

Waiblinger HU, Grohmann L, Mankertz J, Engelbert D, Pietsch K (2010) A practical approach to screen for authorised and unauthorised genetically modified plants. Anal Bioanal Chem 396:2065-2072 